\title{
Profile of Infectious Spondylodiscitis in Rheumatology Consultation at University Teaching Hospital of Kara, Togo
}

\author{
Prenam Houzou ${ }^{1}$, Awaki-Esso Atake1, Kodjo Kakpovi², Viwale E. Koffi-Tessio ${ }^{3}$, Komi C. Tagbor $^{4}$, \\ Eyram Fianyo4, Sadat Oniankitan1, Mamadou L. Diallo', Pahimi Yibe ${ }^{3}$, Erika Djougnwe Mba4, \\ Poyode Lokou', Owonayo Oniankitan³, Moustafa Mijiyawa ${ }^{3}$
}

${ }^{1}$ Department of Rheumatology, University Teaching Hospital of Kara, Kara, Togo

${ }^{2}$ Department of Rheumatology, Regional Hospital of Kara Tomdè, Kara, Togo

${ }^{3}$ Department of Rheumatology, University Teaching Hospital Sylvanus Olympio, Lomé, Togo

${ }^{4}$ Department of Rheumatology, District Hospital of Bè, Lomé, Togo

Email: ^h_prenam@yahoo.fr

How to cite this paper: Houzou, P., Atake, A.-E., Kakpovi, K., Koffi-Tessio, V.E., Tagbor, K.C., Fianyo, E., Oniankitan, S., Diallo, M.L., Yibe, P., Mba, E.D., Lokou, P., Oniankitan, O. and Mijiyawa, M. (2021) Profile of Infectious Spondylodiscitis in Rheumatology Consultation at University Teaching Hospital of Kara, Togo. Open Journal of Rheumatology and Autoimmune Diseases, 11, 160-168. https://doi.org/10.4236/ojra.2021.114017

Received: August 21, 2021

Accepted: October 16, 2021

Published: October 19, 2021

Copyright $\odot 2021$ by author(s) and Scientific Research Publishing Inc. This work is licensed under the Creative Commons Attribution International License (CC BY 4.0).

http://creativecommons.org/licenses/by/4.0/ (c) (i) Open Access

\begin{abstract}
Objectives: The objective is to determine the frequency and the semiological and evolutionary profiles of infectious spondylodiscitis in hospital practice in Kara. Patients and methods: This was a cross-sectional study of a case series of patients with infectious spondylodiscitis, who were admitted to the rheumatology department of Kara University Hospital in North Togo. Results: Among the 3972 examined patients, 86 (33 males and 53 females) patients $(2.16 \%)$ had infectious spondylodiscitis. The average age of these patients at the onset of the disease was 47.20 years. The average duration of the disease was 11.41 months. Tuberculosis was suspected in 77 of 86 patients $(89.53 \%)$. The infectious spondylodiscitis most often affected the lumbar (51.04\%) and dorsal (21.87\%) segments and was associated with a pulmonary location in 31 patients $(36.04 \%)$. In addition to underdevelopment and poor hygiene (72 cases), alcoholism (15 cases) and human immunodeficiency virus infection (10 cases) were the main risk factors identified. The progress with the medical treatment was favorable in 65 patients $(75.58 \%)$ and 16 patients were lost to follow-up. Conclusion: The frequency of infectious spondylodiscitis reflects the underdevelopment and poor hygiene levels in Black Africa. Its etiology is most commonly associated with tuberculosis and remains a concern despite the epidemiological transition of the different diseases.
\end{abstract}




\section{Keywords}

Infection, Spondylodiscitis, Tuberculosis, Black Africa

\section{Introduction}

Osteoarticular infections play a significant role in rheumatology practice. Infectious spondylodiscitis is an infection of the intervertebral disc and adjacent vertebral bodies, rarely affecting the posterior inter-apophyseal joints [1]. Although it is a ubiquitous condition with uneven distribution across the globe [1] [2] [3], more than $90 \%$ of cases have been reported in developing countries [4]. According to the World Health Organization, tuberculosis remains the leading cause of infection-related mortality worldwide, affecting about 10 million people in 2019, with 1.2 million deaths mostly in underdeveloped and developing countries [4]. Infectious spondylodiscitis is a real diagnostic and therapeutic emergency. Indeed, these are potentially serious conditions that risk the functional and sometimes vital prognosis of the patient, with long-term chronic disabling sequelae and significant social costs [5] [6]. Many studies have been conducted on infectious spondylodiscitis in Africa [7] [8] [9] [10] and revealed the important part of Pott disease. In Togo, these studies were conducted in the capital city of Lomé [11] [12], and infectious spondylodiscitis accounted for $1.5 \%$ of all rheumatic diseases occurring there. The absence of specific data on infectious spondylodiscitis in semi-rural areas in the northern part of Togo was the motivation for this study. It aimed to determine the frequency and the semiological and evolutionary profiles of this condition in the hospital practice in Kara.

\section{Patients and Methods}

This was a cross-sectional study conducted on the files of patients suffering from infectious spondylodiscitis. The records of patients with this condition, who were admitted to the rheumatology department of the University Teaching Hospital of Kara (420 km north of Lomé) were analyzed. That department welcomes rheumatic patients from the three northern regions of Togo composed mainly of young and rural population [13]. The study involved patients admitted from April 2013 to June 2020. All patients received imaging of the painful part of the spine and chest X-ray. The positive diagnosis was retained on the radioclinical arguments. No patient performed discovertebral biopsy for technical reasons. The etiological diagnosis was based on microbiological isolation and/or demonstration of characteristic histological lesions (caseous granulomatous inflammation for tuberculosis), epidemiological context of endemicity of Koch's Bacillus in Sub-Saharan Africa [4], and a strong clinical suspicion (existence of another infection, particularly pulmonary tuberculosis, with typical appearance on imaging or a favorable response to antibiotic treatment). Sociodemographic aspects, clinical and paraclinical characteristics, treatment, progress, and follow-up 
of patients were the different parameters studied. Data entry was performed using Epidata version 3.1 software. The data were analyzed using Epi-Info 7.2.4.0 software with chi-square tests, with significance level set at $\mathrm{p} \leq 0.05$.

\section{Results}

\subsection{Sociodemographic Data}

Of the 3972 patients admitted during the study period, 86 had infectious spondylodiscitis (2.16\%). The female to male sex ratio was 1.60 , and the mean age of the patients at the first consultation was $47.20 \pm 15.95$ years (range, 6 - 80 years). The mean age was $49.43 \pm 17.18$ years for females and $43.63 \pm 13.20$ years for males $(\mathrm{p}=0.2267)$. Traders $(31.40 \%)$, farmers $(29.07 \%)$, and civil servants (9.30\%) were the main socio-professional categories affected. Poor hygiene and promiscuity (72 cases; $83.72 \%$ ) and chronic alcoholism (15 cases; $17.44 \%)$ were found to be the main risk factors for infection in the patients (Table 1).

\subsection{Clinical Data}

The pain was the main reason for the patients to visit the hospital. It was mechanical in $54.65 \%$ of the cases, inflammatory in $32.56 \%$, and mixed in $12.79 \%$. The average duration of the evolution of the symptomatology before the rheumatological consultation was $11.41 \pm 24.25$ months (range, 5 days - 44 months). An alteration of the general state was noted in $80.23 \%$ of the cases, with weight loss in $70.93 \%$ of them. The lungs ( 22 cases; $50 \%$ ), lymph nodes ( 9 cases; $20.45 \%$ ), and urogenital tract (4 cases; $9.09 \%$ ) were the main extraspinal infectious sites associated.

\subsection{Paraclinical Data}

Spondylodiscitis lesions were found on standard radiography in $63.62 \%$ of cases, on computed tomography scans in $33.72 \%$ of cases, and on magnetic resonance imaging (MRI) in $2.32 \%$ of cases. Two cases $(2.32 \%)$ of spondylitis were confirmed on radiography. The L3 - L4 and L4 - L5 discs were most commonly affected (29.07\%). Epiduritis was observed in $15.11 \%$ of patients. Ultrasound examination revealed psoas abscess in two patients. Chest radiography was abnormal in 31 cases, with pleurisy observed in $41.94 \%$ of the cases (Table 2).

Table 1. Distribution of patients according to the contributing factors.

\begin{tabular}{ccc}
\hline & Number $(\mathrm{n}=86)$ & Percentage \\
\hline Inadequate hygiene and promiscuity & 72 & 83.72 \\
Ethylism & 15 & 17.44 \\
HIV infection & 10 & 11.62 \\
Diabetes & 3 & 3.48 \\
Hemoglobinopathy & 3 & 3.48 \\
Smoking & 2 & 2.32 \\
\hline
\end{tabular}

${ }^{a}$ Human immunodeficiency virus. 
Table 2. Distribution of different associated lung lesions.

\begin{tabular}{ccc}
\hline & Number $(\mathrm{n}=31)$ & Percentage \\
\hline Pleurisy & 13 & 41.94 \\
Alveolar syndrome & 6 & 19.35 \\
Miliary tuberculosis & 5 & 16.13 \\
Alveolar-interstitial syndrome & 5 & 16.13 \\
Axillary opaque nodule & 2 & 6.45 \\
\hline
\end{tabular}

The tuberculosis origin of infectious spondylodiscitis (Pott's disease) was considered probable in 76 patients $(90.78 \%)$ and certain in 1 patient $(1.16 \%)$, which was confirmed by the histological examination of a lymph node biopsy specimen of cervical adenopathy. The role of a pyogenic bacteria was confirmed in two cases $(22.22 \%)$ and considered probable in seven cases $(77.78 \%)$. The isolated microbes were Pseudomonas aeroginosa on cytobacteriological examination of urine and Streptococcus agalactiae on cytobacteriological examination of joint fluid. Table 3 summarizes the main characteristics and paraclinical findings of infectious spondylodiscitis according to the causative microorganism.

\subsection{Therapeutic and Evolutionary Data}

The 77 patients with Pott's disease were treated with a combination of rifampin, isoniazid, ethambutol, and pyrazinamide. Decompressive surgery was performed in a 6-year-old girl with probable Pott's disease complicated by cervical spinal cord compression with a large paravertebral abscess and bone sequestration (Figure 1). Pyogenic spondylodiscitis was treated with broad-spectrum antibiotics in all 9 patients. All patients received analgesic treatment: $29.06 \%$ of the patients received nonsteroidal anti-inflammatory drugs and $49.35 \%$ received oral corticosteroid therapy. All patients were subjected to immobilization of the painful part. Functional rehabilitation was performed in $41.86 \%$ of cases. The progress was favorable in $75.58 \%$ of the patients, including the operated patient who was able to walk again 72 hours after the operation. Sequelae such as persistent functional impotence of the lower limbs were observed in three patients, one of whom was human immunodeficiency virus (HIV) positive and the other had chronic renal failure. Two patients died of probable pulmonary embolism. The remaining $18.60 \%$ of patients were lost to follow-up.

\section{Discussion}

Infectious spondylodiscitis accounted for $2.16 \%$ of the cases of rheumatologic diseases at University Teaching Hospital of Kara. This frequency is close to that reported in Lomé, which was $1.5 \%$ in 20 years [12]. The average age of the patients was 47.20 years, similar to that reported by other African authors [14] [15] [16]. However, this means age was lower than that reported in the West [17] [18], where patients in their 50s and 60s are more commonly affected. This 


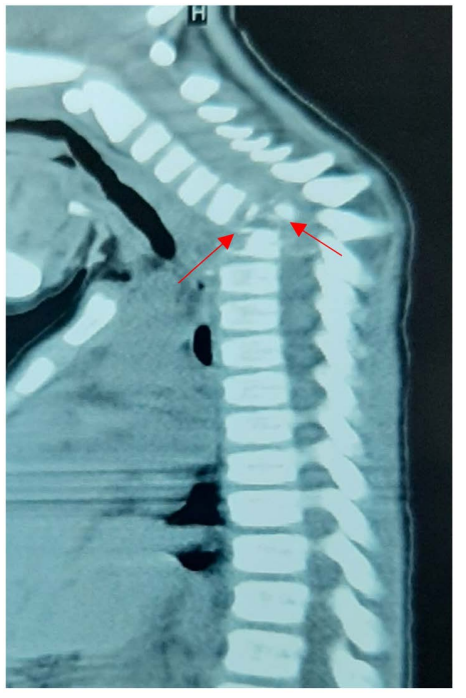

Figure 1. Computed tomography image of C7 and D1 bifocal spondylitis with epiduritis and intramedullary bone sequestration (red arrows).

Table 3. Main clinical and paraclinical manifestations observed in the patients with infectious spondylodiscitis $(\mathrm{n}=86)$.

\begin{tabular}{|c|c|c|c|}
\hline & $\begin{array}{c}\text { Tuberculous } \\
\text { spondylodiscitis } \\
(\mathrm{n}=77) \\
\text { Number }(\%)\end{array}$ & $\begin{array}{c}\text { Pyogenic } \\
\text { spondylodiscitis } \\
(\mathrm{n}=9) \\
\text { Number }(\%)\end{array}$ & Probability \\
\hline Progressive installation & $64(83.11)$ & $1(11.11)$ & 0.0161 \\
\hline Inflammatory pain & $19(24.67)$ & $9(100.00)$ & 0.0002 \\
\hline Mechanical pain & $47(61.03)$ & $1(11.11)$ & 0.0515 \\
\hline Cervical seat & $2(2.59)$ & $1(7.81)$ & 0.2088 \\
\hline Cervicodorsal hinge & $1(1.29)$ & 0 & 0.7277 \\
\hline Back seat & $19(24.67)$ & $2(22.22)$ & 0.8499 \\
\hline Dorsolumbar hinge & $16(20.77)$ & $1(11.11)$ & 0.5132 \\
\hline Lumbar location & $45(58.44)$ & $4(44.44)$ & 0.5513 \\
\hline Lumbosacral hinge & $5(6.49)$ & $1(11.11)$ & 0.6437 \\
\hline Multifocal location & $9(11.68)$ & $1(11.11)$ & 0.9346 \\
\hline Abscess & $9(11.68)$ & $1(11.11)$ & 0.9346 \\
\hline Fever & $7(9.09)$ & $8(88.88)$ & 0.0000 \\
\hline Gibbosity & $33(42.85)$ & $1(11.11)$ & 0.1396 \\
\hline Spinal cord compression & $23(29.87)$ & $1(11.11)$ & 0.2948 \\
\hline Overall stiffness & $50(64.93)$ & $9(100.00)$ & 0.2710 \\
\hline Root syndrome & $33(42.85)$ & $6(66.66)$ & 0.3569 \\
\hline $\mathrm{ESR}^{\mathrm{a}}$ greater than $20 \mathrm{~mm}$ & $70(90.90)$ & $8(88.88)$ & 0.8758 \\
\hline Deaths & $2(2.59)$ & 0 & 0.6225 \\
\hline
\end{tabular}

aerythrocyte sedimentation rate. 
reflects the relatively young age of the African population affected by infectious spondylodiscitis. In this study, females were more commonly affected, contrary to the observations of another study conducted in Lomé [12]. The disease seemed to affect all patients without distinction of sex. Traders and farmers were the most commonly affected professional categories in our study. This was different from the findings of a study conducted in Cotonou, Benin, where office workers were predominantly affected [7]. This difference could be partly explained by the geographical setting of North Togo, which is a semi-rural area, and the low level of education of most of these professions that makes them susceptible to poor hygiene levels. Immunosuppression due to HIV infection modifies the frequency of infectious spondylodiscitis only in areas of high seroprevalence, as it was the third risk factor after underdevelopment and poor hygiene in our study as well as other African studies [7] [12].

Patients often seek consultation at the stage of neuro-orthopedic complications. The delay in consultation and long duration of disease progression are responsible for delayed diagnosis in developing countries [19] [20] [21] as compared to the developed countries [22] [23]. This long delay in progression of the disease is often a reflection of the infectious tuberculosis pathology, which is reputed to be nonspecific with a slow and torpid evolution. The uneven distribution of the infection along the spine is known and has been demonstrated by data in the literature [10] [17] [24]. In our study, signs of infectious spondylodiscitis were revealed on standard radiography in $63.95 \%$ of cases. This high rate is related to the long diagnostic delay that favors the appearance of the lesions. The financial and geographical accessibility of modern imaging remains a health challenge in the northern part of Togo, where a low rate of realization of computed tomography and MRI is noted, contrary to that observed in other African and Western countries [18] [25] [26]. If conventional X-rays remain the first-line examination in the investigation of vertebral pain in a febrile context, MRI is the reference examination for the confirmation of spondylodiscitis. Discovertebral abnormalities appear as early as the fifth day, while the changes are not visible on X-rays until after two weeks [27]. The predominance of the tuberculous etiology found in our study confirms the findings of other African authors [8] [10] [12] [28] [29], highlighting the endemicity of the Mycobacterium tuberculosis in the African continent. Pyogenic spondylodiscitis seems to be rare in our environment [7]. However, in Developed countries, they represent the first etiology and are more favored by diabetes, alcoholism and chronic kidney disease [1] [17] [23] [30]. Besides, its incidence seems to be increasing as a result of the increase in spinal instrumentation and surgery and with a higher life expectancy of older patients with chronic debilitating diseases in that countries [31] [32].

The treatment of infectious spondylodiscitis is conservative in most cases, combining targeted antibiotic therapy and immobilization. The indications for surgery are limited, and reserved for the treatment of acute neurological compression due to abscess or bone sequestration [20] [29] [33]. However, regardless 
of the therapeutic protocol, the evolutionary modalities overlap [12] [29] [34]. The outcome was favorable in $75.58 \%$ of our patients. The high rate of patients lost to follow-up is partly explained by the low socio-economic level of patients who are unable to honour follow-up assessments and appointments [13]. Although the limitations of this study include evaluation of cases from a single center and the failure of the technical platform, this work had an undeniable epidemiological and management interests for infectious spondylodiscitis in this part of Africa.

\section{Conclusion}

Infectious spondylodiscitis is a common reason for patient consultation in North Togo. The high proportion of tuberculous spondylodiscitis cases testifies to the persistence of the endemicity of Koch's bacillus in the African continent, where underdevelopment and insufficient hygiene are the main factors favoring it. The effective management of infectious spondylodiscitis is hindered by the delay in consultation, which is a characteristic of most diseases in this region. However, although the prognosis of the disease is usually favorable with medical treatment, it would be important to conduct further studies to evaluate the socio-economic impact of this condition in our country.

\section{Conflicts of Interest}

The authors declare no conflicts of interest regarding the publication of this paper.

\section{References}

[1] Grammatico, L. and Besnier, J.-M. (2007) Infectious Spondylodiscitis. Revue du praticien, 57 , 970-978.

[2] Jevtic, V. (2004) Vertebral Infection. European Radiology Supplements, 14, E43-E52. https://doi.org/10.1007/s00330-003-2046-x

[3] Lener, S., Hartmann, S., Barbagallo, G.M.V., Certo, F., Thomé, C. and Tschugg, A. (2018) Management of Spinal Infection: A Review of the Literature. Acta Neurochirurgica, 160, 487-496. https://doi.org/10.1007/s00701-018-3467-2

[4] World Health Organization (2020) Global Tuberculosis Report 2020: Executive Summary. World Health Organization, Geneva. https://apps.who.int/iris/bitstream/handle/10665/337538/9789240016095-eng.pdf.

[5] Robertson, F.C., Lepard, J.R., Mekary, R.A., Davis, M.C., Yunusa, I., Gormley, W.B., et al. (2018) Epidemiology of Central Nervous System Infectious Diseases: A Meta-Analysis and Systematic Review with Implications for Neurosurgeons Worldwide. Journal of Neurosurgery, 130, 1107-1126. https://doi.org/10.3171/2017.10.JNS17359

[6] Zeller, V. and Desplaces, N. (2006) Antibiotherapie de infections osteoarticulaires pyogenes chez l'adulte: Principes et modalités. Revue du Rhumatisme, 73, 183-190. https://doi.org/10.1016/j.rhum.2005.09.009

[7] Zomalhéto, Z., Kobelembi, A., Agbodandé, A., Dossou-Yovo, H., Zossoungbo, F. and Avimadjé, M. (2015) Epidemio-Clinical, Paraclinical and Therapeutic Profile of 
Infectious Spondylodiscitis in Hospital Consultation at Cotonou. Medecine d Afrique Noire, 62, 405-410.

[8] N’soundhat, N.L., Moyikoua, R., Mpika, G.M., Ntsiba, H. and Bileckot, R. (2019) Diagnosis of Pott's Disease in the Rheumatology Department of the University Teaching Hospital of Brazzaville. Health Sciences and Disease, 20, 53-57.

[9] Kamissoko, A.B., Diallo, M.L., Traore, M., Diallo, A., Yombouno, E., Barry, A., et al. (2018) Panorama des maladies rhumatismales A Conakry. European Scientific Journal, ESJ, 14, 422-431. https://doi.org/10.19044/esj.2018.v14n24p422

[10] Eti, E., Daboiko, J.C., Brou, K.F., Ouali, B., Ouattara, B., Koffi, K.D., et al. (2010) Spinal Tuberculosis: Our Experience from a Study of 147 Cases in the Rheumatology Department of the University Hospital of Cocody (Abidjan, Ivory Coast). Médecine d Afrique Noire, 57, 287-292.

[11] Oniankitan, O., Kakpovi, K., Agoda-Koussema, L.K., Tagbor, K.C., Fianyo, E., Houzou, P., et al. (2014) Cervical Spondylodiscitis in Hospital Environment in Lomé (Togo). Tunisie Medicale, 92, 567-569.

[12] Oniankitan, O., Bagayogo, Y., Fianyo, E., Koffi-Tessio, V., Kakpovi, K., Tagbor, K.C., et al. (2009) Spondylodiscitis at a Hospital Outpatient Clinic in Lomé, Togo. Médecine Tropicale, 69, 581-582.

[13] Institut National de la Statistique et des Etudes Economiques et Demographiques-Togo (2021) Annuaire statistique nationale 2014-2020.

[14] Gbané-Koné, M., Ouattara, B., Diomandé, M., Sessou, V., Kaboré, F., Djoko, K.F., et al. (2015) Cervical Pains in Pott's Disease: Epidemiological, Clinical and Radiological Aspects Concerning 26 Cases in Abidjan. Mali Medical, 30, 15-18.

[15] Toloba, Y., Diallo, S., Maiga, Y., Sissoko, B., Ouattara, K., Soumaré, D., et al. (2011) Spinal Tuberculosis (Pott's Disease): Epidemiological, Clinical, Radiological and Evolutionary Aspects at the University Hospital of Point G. Mali Medical, 26, 8-11.

[16] Abdelmoula, L., Tekaya, B., Cheikhrouhou, S., Saidane, O., Mahmoud, I. and Tekaya, R. (2017) Spinal Tuberculosis: 12 Years' Experience at a Tunisian Center. Revue Malienne d' Infectiologie et de Microbiologie, 9, 63-80.

https://doi.org/10.53597/remim.v0i9.927

[17] Ponciano, A., Cruz, G., Ventura, C., Rabadão, E. and Saraiva da Cunha, J. (2018) Infectious Spondylodiscitis: 5-Year Analysis of a Tertiary Hospital in Portugal. Infectious Diseases, 50, 637-639. https://doi.org/10.1080/23744235.2017.1419374

[18] Homagk, L., Marmelstein, D., Homagk, N. and Hofmann, G.O. (2019) SponDT (Spondylodiscitis Diagnosis and Treatment): Spondylodiscitis Scoring System. Journal of Orthopaedic Surgery and Research, 14, Article No. 100.

https://doi.org/10.1186/s13018-019-1134-9

[19] N'soundhat, N.E.L., Moyikoua, R., Mpika, G.M., Ntsiba, H. and Bileckot, R. (2019) Morphological Aspects of Pott's Disease in Adult Congolese Patients Living in Brazzaville. Health Sciences and Disease, 25, 64-67.

[20] Maftah, M., Lmejjati, M., Mansouri, A., El Abbadi, N. and Bellakhdar, F. (2001) Pott's Disease about 320 Cases. Médecine du Maghreb, 90, 19-22.

[21] Waheed, G., Soliman, M.A.R., Ali, A.M. and Aly, M.H. (2019) Spontaneous Spondylodiscitis: Review, Incidence, Management, and Clinical Outcome in 44 Patients. Neurosurgical Focus, 46, Article No. E10. https://doi.org/10.3171/2018.10.FOCUS18463

[22] Ben Taarit, C., Turki, S. and Maiz, H. (2002) Infectious Spondylitis. Study of a Series of 151 Cases. Acta Orthopaedica Belgica, 68, 381-387. 
[23] Cebrián Parra, J.L., Saez-Arenillas Martín, A., Urda Martínez-Aedo, A.L., Soler Ivañez, I., Agreda, E. and Lopez-Duran Stern, L. (2012) Management of Infectious Discitis. Outcome in One Hundred and Eight Patients in a University Hospital. International Orthopaedics, 36, 239-244. https://doi.org/10.1007/s00264-011-1445-x

[24] Okay, G., Akkoyunlu, Y., Bolukcu, S., Durdu, B., Hakyemez, I.N. and Koc, M.M. (2018) Analysis of Infectious Spondylodiscitis: 7-Years Data. Pakistan Journal of Medical Sciences, 34, 1445-1451.

[25] Badaoui, L., Dabo, G, Sodqi, M., Marih, L., Oulad lahsen, A. and Chakib, A. (2014) Infectious Spondylodiscitis: Epidemiological, Clinical, Paraclinical, Therapeutic and Evolutive Aspects. Revue Malienne d Infectiologie et de Microbiologie, 3, 29-33.

[26] Gbané-Koné, M., Ouattara, B., Diomandé, M., Sessou, V., Kaboré, F., Djoko, K.F., et al. (2015) Contribution of Computed Tomography in the Diagnosis of Spinal Tuberculosis about 496 Cases in Abidjan. The Pan African Medical Journal, 20, Article No. 201. https://doi.org/10.11604/pamj.2015.20.201.5996

[27] Willaume, T. and Bierry, G. (2021) Imagerie des spondylodiscites infectieuses. Imagerie des spondylodiscites infectieuses-EM consulte (em-consulte.com).

[28] Ladeb, M.F., Riahi, H., Chelli Bouaziz, M. and Mechri, M. (2019) Clinical Evolution of Tuberculous Spondylodiscitis in Tunisia. Bulletin de 1 Académie Nationale de Médecine, 203, 328-333. https://doi.org/10.1016/j.banm.2019.05.001

[29] Sakho, Y., Badiane, S.B., N’Dao, A.K., N’Diaye, A., Gueye, M. and N’Diaye, I.P. (2003) Pott's Disease in Senegal. European Journal of Orthopaedic Surgery \& Traumatology, 13, 13-20. https://doi.org/10.1007/s00590-002-0057-y

[30] Genevay, S. (2006) Spondylodiscite Infectieuse: Le regard du rhumatologue. Revue Médicale Suisse, 57, Article No. 715.

[31] Mylona, E., Samarkos, M., Kakalou, E., Fanourgiakis, P. and Skoutelis, A. (2009). Pyogenic Vertebral Osteomyelitis: A Systematic Review of Clinical Characteristics. Seminars in Arthritis and Rheumatism, 39, 10-17. https://doi.org/10.1016/j.semarthrit.2008.03.002

[32] Akiyama, T., Chikuda, H., Yasunaga, H., Horiguchi, H., Fushimi, K. and Saita, K. (2013) Incidence and Risk Factors for Mortality of Vertebral Osteomyelitis: A Retrospective Analysis Using the Japanese Diagnosis Procedure Combination Database. BMJ Open, 3, Article ID: e002412. https://doi.org/10.1136/bmjopen-2012-002412

[33] Fedoul, B., Chakour, K. and Chaoui, M.E.F. (2011) Pott's Disease: Report of 82 Cases. Pan African Medical Journal, 8, Article No. 22. https://doi.org/10.4314/pamj.v8i1.71078

[34] Polley, P. and Dunn, R. (2009) Noncontiguous Spinal Tuberculosis: Incidence and Management. European Spine Journal, 18, 1096-1101. https://doi.org/10.1007/s00586-009-0966-0 